\title{
Andalusian Registry for Familial Adenomatous Polyposis. Analysis of patients included
}

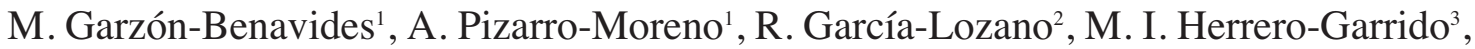 \\ A. J. Hervás-Molina ${ }^{4}$, J. L. Márquez-Galán ${ }^{1}$ and C. Cordero-Fernandez ${ }^{1}$
}

${ }^{1}$ Department of Gastroenterology. ${ }^{2}$ Department of Immunology. Virgen del Rocío University Hospital. Seville, Spain. ${ }^{3}$ Department of Gastroenterology. Jerez de la Frontera Hospital. Cádiz, Spain. ${ }^{4}$ Department of Gastroenterology. Reina Sofía University Hospital. Córdoba, Spain

\begin{abstract}
Objective: To evaluate the phenotype and genotype characteristic of patients included in the Andalusian Registry for familial adenomatous polyposis, the genotype/phenotype correlation and the impact of Registry in the frequency of colorectal cancer of registered.

Material and methods: A descriptive study of 77 patients with FAP belonging to 33 families, included in a centralized database visited by the physicians of the hospitals taking part in the present study, on prior signing of confidentiality letters. All genetic studies were carried out in the Immunology Service of our institution.

Results: We have included in our study 77 patients of 33 families; 31 probands with a mean age of 32 years (13-51) and 46 relatives at risk with a mean age of 21.8 years (6-55). Genetic study informed in $68 / 77$ with positive result in $92.6 \%$. Ten probands showed colorectal cancer (CRC) at the time of diagnosis (32.2\%). Only two affected relatives showed CRC at diagnosis $(4.3 \%)$, a statistically significant difference $(p<0.05)$. Gastrointestinal involvement was observed in 30/61 (49\%), desmoid tumors in $7 / 77(9.1 \%)$ and congenital hypertrophy of the retinal pigment epithelium in $23 / 55$ (65.7\%). $86.7 \%$ of patients with this alteration showed mutations between codons 454 and 1019, with a statistically significant correlation $((p<0.05)$

Conclusions: The registry has facilitated the genetic diagnosis for all affected families disregard their province of origin. It has also improved the screening of affected relatives and has made it possible to take preventive measures immediately, therefore diminishing the incidence of $\mathrm{CRC}$ at diagnosis in registered affected relatives. The correlation between congenital hypertrophy of the retinal pigment epithelium with some mutations is the only phenotypic-genotypic correlation with statistical significance.
\end{abstract}

Key words: familial adenomatous polyposis; phenotype; genotype; FAP registry; APC gene; genetic counseling; genetic study; Hereditary cancer.

Receive: $18-03-10$

Accepted: 07-07-10.

Correspondence: Marta Garzón Benavides. Servicio de Aparato Digestivo. Hospital Universitario Virgen del Rocío. Avda. Manuel Siurot, s/n. 41013 Sevilla, Spain.e-mail: mgarzonb@hotmail.com

\section{RESUMEN}

Objetivos: Valorar las características fenotípicas y genotípicas de los pacientes incluidos en el Registro Andaluz de la poliposis adenomatosa familiar, la relación genotipo/fenotipo y el impacto del Registro en la frecuencia de cáncer colorrectal de los familiares registrados.

Material y métodos: Estudio descriptivo de 77 pacientes con PAF, pertenecientes a 33 familias, incluidos en una base de datos centralizada a la que tienen acceso los responsables de los hospitales participantes, previa firma de cartas de confidencialidad. Todos los estudios genéticos se realizan en el Servicio de Inmunología de nuestro Hospital.

Resultados: 77 pacientes registrados (50,6\% varones): 31 probandos, edad media: 32 años (13-51) y 46 familiares afectos, edad media 21,8 años (6-55). Estudio genético informado en $68 / 77$ con resultado positivo en $92,6 \%$. Cáncer colorrectal al diagnóstico en diez probandos $(32,2 \%)$ y 2 familiares afectos $(4,3 \%)$, diferencia estadísticamente significativa $(p<0,05)$. Se observó afectación de tramos altos en 30/61 (49\%), tumor desmoides en $7 / 77(9,1 \%)$ e hipertrofia del epitelio pigmentario de la retina en 23/35 (65,7\%). El 86,7\% de los pacientes con esta alteración mostraron mutaciones entre los codones 454 y 1.019 , relación estadísticamente significativa $(p<0,05)$.

Conclusiones: El Registro Andaluz ha permitido ofrecer el diagnóstico genético en todas las familias afectas independientemente de su provincia de origen, mejorar el cribado, iniciar medidas preventivas precozmente y disminuir la frecuencia de cáncer colorrectal al diagnóstico en los familiares afectos registrados. La relación de la hipertrofia congénita del epitelio pigmentario de la retina con determinadas mutaciones es la única relación feno-genotípica con significación estadística

Palabras clave: Poliposis adenomatosa familiar. Registro de PAF. Gen APC. Consejo genético. Estudio genético. Cáncer hereditario.
Garzón Benavides M, Pizarro Moreno A, García Lozano R, Herrero Garrido MI, Hervás Molina AJ. Márquez Galán JL, Cordero Fernandez C. Andalusian registry for familial adenomatous polyposis. Analysis of patients included. Rev Esp Enferm Dig 2010; 102: 653-657. 


\section{INTRODUCTION}

FAP is an autosomal dominant inherited disorder caused by a germline mutation in the adenomatous polyposis coli (APC) gene (1). It is characterized by the development of multiple polyps throughout the colon and rectum, generally more than 100 , which become malignant in $100 \%$ of affected patients by an early age (35-40 years) (1). A variant is attenuated familial adenomatous polyposis (AFAP), characterized by late age at onset (10 years) with fewer polyps (10-100), predominantly in the right colon $(2,3)$.

Gastroduodenal involvement, mainly of the duodenum, also appears in $90-100 \%$ of patients $(4,5)$ with an incidence of malignancy in the periampullary area ranging between 4 and 12\%. (6). Special mention must desmoid tumor (DT) to be the extra-colonic neoplasia most frequent in these patients $(8-12 \%)$ and second leading cause of death in patients with prophylactic colectomy (7). Another important manifestation is congenital hypertrophy of retinal pigment epithelium (CHRPE), that appears in a high percentage of patients with FAP (up to $80 \%$ in some series), and when they are multiple and bilateral have sensitive screening capacity (3).

It is therefore a complex disease that requires to proceed in the family environment for its hereditary feature and initiate preventive measures and early treatment. The creation of registries of families with FAP in other countries and communities has reduced the frequency of CCR and improve survival in these patients (1). We consider necessary to offer these results to the entire population of Andalusia.

In 2006 the Andalusian registry of FAP (ARFAP) was created with the objective of offering genetic testing to all affected families in our community, facilitate and standardize the diagnosis and treatment of all affected individuals. After more than three years of operation, a review of the data contained in the ARFAP to know the phenotypic and genotypic characteristics of FAP in Andalusia, the genotype-phenotype correlation and the impact of its creation in reducing the frequency of CRC in affected relatives diagnosed by screening.

\section{MATERIAL AND METHODS}

We performed a descriptive study of patients with FAP included in the ARFAP. The creation of the registry was made in 2003 between the Prevention of CRC Consultation Service of Gastroenterology of the Hospital "Virgen del Rocío" in Seville, Spain, and the Immunology Department of the Hospital. Fourteen Gastroenterology Units of hospitals of the 8 provinces of Andalusia were contacted to inform them about the project. The Registry was presented at the different meetings held by the Sociedad Andaluza de Patología Digestiva (Andalusian Society of Digestive Tract Pathology) where the physicians responsible for the different hospitals taking part in the project were appointed.

With support from the Clinical Documentation Service of our Hospital, a website was created that contains the centralized database. In January 2006 first patients began to be included. For their inclusion, patients had to show clinical and or molecular criteria of FAP. The variables were: age, sex, family history of FAP, type of prophylactic surgery (total colectomy with ileorectal anastomosis, subtotal colectomy with ileorectal anastomosis, definitive ileostomy), the presence of CRC at diagnosis, staging of CRC according to TNM classification, treatment applied, involvement of high segments, its staging according to Spigelman classification, treatment (polypectomy, ampullectomy, cephalic pancreatectomy with preservation of pylorus, etc.), extraintestinal manifestations (DT, CHRPE, thyroid tumor, hepatoblastoma), development of rectal stump cancer, its staging according to TNM, surgical treatment and characteristics of the mutations found.

Access to the database is done through a unique password for each physician, acquired after signing a letter of confidentiality, thereby applying the principles of the Organic Law of Protection of Personal Data (LOPDP).

To ensure the appropriate operation of the Registry and proper use of its data was created the Scientific Committee, composed of physicians in charge of the hospitals with more participation ("Virgen del Rocio" Hospital in Seville, "Reina Sofia" Hospital in Cordoba and Jerez de la Frontera Hospital of Cadiz, and the Immunology Department of the "Virgen del Rocío" Hospital).

We have carried out descriptive analysis of the quantitative and qualitative variables. The comparative analysis of the qualitative variables was carried out by means of the Chi-Square test, considering statistical significance when $p<0.05$. It has been used the statistical program SPSS 13.0 (SPSS Inc. Headquarters, Chicago, Illinois, he USES).

\section{RESULTS}

From January 2006 through June 2009, 4 of the 14 hospitals initially invited have taken part in the ARFAP ("Reina Sofía" Hospital from Córdoba, Jerez de la Frontera Hospital from Cádiz, "Torrecárdenas" Hospital from Almería, "Virgen del Rocío" Hospital from Seville), representing a participation of $28.5 \%$.

During this period, 77 patients belonging to 33 families with an average age of 26 years (13-51) (50.6\% males and $49.4 \%$ females) have been enrolled in the project. Thirty one $(40.3 \%)$ were probands (mean age of 32 years; range: $13-53$ years) and $46(59.7 \%)$ were affected relatives diagnosed by screening (mean age of 22 years; range 6-55 years).

The percentage of CCR at the time of diagnosis was $32.3 \%$ in probands (10/31), and $4.3 \%$ in the affected relatives (2/46), statistically significant difference $(p<$ 
0.05).The two affected relatives were asymptomatic at diagnosis and had older ages than other family members (32 and 42). The CRC in $40 \%$ of probands (4/10) was in an advanced TNM stage (IV), and in the two relatives at risk the stage was intermediate (I and IIIB). Only a proband developed rectal stump cancer after follow-up cessation during two years. There were no cases of rectal stump cancer among affected relatives (Table I).

Table I. Digestive manifestations of FAP

\begin{tabular}{lccc}
\hline & $\begin{array}{c}\text { Probands } \\
(n=31)\end{array}$ & $\begin{array}{c}\text { Affected relatives } \\
(n=46)\end{array}$ & $p$ \\
\hline $\begin{array}{l}\text { Degenerated Polyposis at } \\
\text { diagnosis }\end{array}$ & $10 / 31(32.3 \%)$ & $2 / 46(4.34 \%)$ & $<0.05$ \\
\hline \multicolumn{4}{c}{ TNM classification } \\
\hline I & $1 / 10(10 \%)$ & $1 / 2(50 \%)$ & \\
IIA & $3 / 10(30 \%)$ & & \\
IIB & 0 & & \\
IIIB & 0 & $1 / 2(50 \%)$ & \\
IIIC & $2 / 10(20 \%)$ & \\
IV & 0 & $16 / 37(43.2 \%)$ & $>0.05$ \\
Gastrointestinal involvement & $4 / 10(40 \%)$ & \\
\hline \multicolumn{4}{c}{ Site of adenomas } \\
\hline Fundus & $5 / 16.3 \%)$ & $>0.05$ \\
Duodenum & $5 / 14(35.7 \%)$ & $8 / 16(50 \%)$ & \\
Peripapillar area & $10 / 14(71.4 \%)$ & $10 / 16(62.5 \%)$ & $>0.05$ \\
\hline & $9 / 14(64.3 \%)$ & $6 / 16(37.5 \%)$ & $>0.05$ \\
\hline
\end{tabular}

In 61 patients it was studied the involvement of the stomach and duodenum. Polyps were found in $49.1 \%$ (58.3\% in probands vs. $43.2 \%$ in affected relatives). The duodenum was the most common location of polyps, $66.6 \%$ of patients, the figures being slightly higher in probands than in affected relatives (71.4 vs. 62.5\%).It was followed by the peripapillary area with $50 \%$ of patients (64.3\% probands vs. 37.5\% affected relatives). Polyps were found in fundus in $43.3 \%$, with greater frequency in affected relatives (50 vs. $35.7 \%$ in probands). Duodenal cancer was developed by one proband 10 years after follow-up cessation. The severity of the duodenal involvement was graded according to Spigelman staging (Table II). No statistically significant differences were found for the location or the severity of the affected upper segments between the two groups of patients (Table I).

Thirty-five of the 77 patients had ophtalmoscopy and 23 of them $(65.7 \%)$ showed HCEPR (Table III). Seven of 77 patients $(9.1 \%)$ developed DT. 4 Were located in the mesentery and 3 in the abdominal wall on laparotomy scars (Table III). Genetic study was performed to 74 of 77 patients. Of the 68 patients with the study completed, mutation was found in 63 (92.6\%). $61 \%$ of the mutations are located in exon 15 . We have found 11 new mutations not previously described. Table IV lists the types of mu-
Table II. Spigelman's Clasiffication

\begin{tabular}{lccc}
\hline & 1 & 2 & 3 \\
\hline$N^{\circ}$ of polyps & $1-4$ & $5-20$ & $>20$ \\
\hline Size & $1-4$ & $5-10$ & $>10$ \\
\hline Histology & Tubular & Tubulovellous & Vellous \\
\hline Dysplasia & Mild & Moderate & Severe \\
\hline
\end{tabular}

Staging according to score: Stage 0: 0 points; stage I: 1-4 points; stage II: 5-6 points; stage III: 7-8 points; stage IV: 9-12 points.

Table III. Extra digestive manifestations of FAP

\begin{tabular}{lc}
\hline CHRPE & Patients $(n=77)$ \\
\hline Desmoid tumor & $23 / 35(65,7 \%)$ \\
\hline Others & $7 / 77(9,1 \%)$ \\
\hline CHRPE: congenital hypertrophy of retinal pigment epithelium.
\end{tabular}

tations found. The statistical study of possible correlations between the types of mutations found and the different manifestations of FAP (colon, extra-colonic and extra-digestive: DT and CHRPE) was statistically significant for CHRPE because $86.7 \%$ of HCEPR patients presented the mutation between codons 454 and

Table IV. List of the type of mutations found

\begin{tabular}{|c|c|c|c|}
\hline Mutation (nucleotids) & $N^{0}$ of families & Type & Exon \\
\hline & 1 & & \\
\hline 707delA & 1 & Deletion & 6 \\
\hline $904 C>T$ & 1 & Termination codon & 8 \\
\hline 3927_3931delAAAGA & 5 & Deletion & 15 \\
\hline 1409_1412delG & 1 & ARN processing $\left({ }^{*}\right)$ & Intron 10 \\
\hline $1787 \bar{C}>G$ & 1 & Termination codon & 14 \\
\hline IVS7+1G>A & 1 & ARN processing $\left(^{*}\right)$ & Intron 7 \\
\hline 1946_1947insC & 1 & Insertion & 14 \\
\hline $2977 A>T$ & 2 & Termination codon & 15 \\
\hline 3224dupA & 1 & Insertion & 15 \\
\hline 2494_2496delC & 1 & Deletion & 15 \\
\hline 2838_2839del AT & 1 & Deletion & 15 \\
\hline 730_731delAG & 1 & Deletion & 7 \\
\hline $637 \bar{A}>T$ & 1 & Termination codon & 5 \\
\hline 2136_2139delTTCA & 1 & Deletion & 15 \\
\hline 2227_2228dupAT & 1 & Insertion & 15 \\
\hline 3582_3583delAT & 1 & Deletion & 15 \\
\hline $847 C>T$ & 1 & Termination codon & 8 \\
\hline $1297 C>T$ & 1 & Termination codon & 9 \\
\hline 1972_1975delGAGA & 1 & Deletion & 15 \\
\hline 4666_4667indA & 1 & Insertion & 15 \\
\hline 3595_3596delAA & 1 & Deletion & 15 \\
\hline $1450 \bar{C}>T$ & 1 & Termination codon & 15 \\
\hline 4342delA & 1 & Deletion & 15 \\
\hline 556 delA & 1 & Deletion & 5 \\
\hline 3183_3187delACAAA & 1 & Deletion & 15 \\
\hline $1690 C>T$ & 1 & Termination codon & 13 \\
\hline $311 C>G$ & 1 & Termination codon & 3 \\
\hline
\end{tabular}

$\left(^{*}\right)$ Mutation of families with FAP that present an affected relative with AFAP. 
1019 , a statistically significant correlation $(\mathrm{p}<0.05)$. The remaining correlations between phenotype and genotype were not significant. Among patients registered there are only two cases of attenuated familial adenomatous polyposis (AFAP), both within families with classic FAP (Table IV).

\section{DISCUSSION}

Genetic study and counselling become vital to manage Familial Adenomatous Polyposis due to the features of this condition, its serious and incurable character despite early preventive therapy, the strict follow up patients require and its hereditary factors.

The importance of genetic study is to permit the exclusion of the disease in some relatives and therefore without risk of transmitting to their offspring, leading to psychological, health and society benefits. This is also a cost-effective measure as shown by some studies (8).

As not all health professionals carry out genetic counseling adequately or cannot interpret the results of a genetic study $(9,10)$ it is necessary to create specialized medical units to deal with these patients (11). But due to the low incidence of FAP, it becomes necessary to create cooperative groups at a regional, national or even international level to unify treatment criteria (11) and perform a correct genetic counseling (10).

This is the origin of the first registries; the one in San Marcos Hospital in London is the first on record (1925) $(12,13)$ with the following objectives: to follow up all relatives at risk, to ensure their timely study and to broaden knowledge about this condition (14).

Lockhart-Mummery was the first physician to point out that the registry and follow up of families with polyposis helped to reduce the number of patients with CRC (15). Afterwards, multiple registries have proved that the centralization of families in registries and the coordinated follow up and treatment of these families makes it possible to reduce the incidence of CRC and to improve survival rates $(1,16,17)$.

Since the creation of the ARFAP, all relatives at risk have undergone a genetic study irrespective of their province of origin. We have found the mutation in $92.6 \%$ of the patients under study, a number which surpasses other series whose incidence ranges from 30 to $85 \%$ (18). When analyzing the genotype-phenotype correlation we have only observed a relationship between the location of the mutation and the presence of CHRPE. Other studies have also observed a correlation between the number of polyps in the resected sample, number and severity of duodenal and gastric adenomas and presence of DT $(19,20)$. Thus, some studies state that the location of the mutation may determine the type of surgical intervention and even delay such intervention in patients with expected risk of developing a DT (18). Nevertheless, the great phenotypic variability among the same family suggests that, apart from the specific APC gene mutation, the influence of modifying genes or even environmental factors must be responsible for the phenotypic features of the different members of the family $(18,21)$. Therefore, the most widespread opinion is that, although genetics is fundamental for the molecular diagnosis, it cannot accurately predict the course of the disease and therefore it cannot determine surgical management (18).

From the study of the registry data we conclude that the invitation to further analysis has allowed us to identify affected relatives at an earlier age (affected relatives, 22 years old $v s$. probands, 32 years old), to establish preventive measures at earlier ages and to diminish the incidence of CRC among affected relatives ( 2 affected relatives $(4.3 \%)$ in comparison to 10 probands $(32 \%)$ statistically significant difference $(\mathrm{p}<0.05)$. We also observed differences in tumor staging: $40 \%$ of probands had a IV stage of TNM classification unlike affected relatives who showed an initial and intermediate stage (I and IIIB, respectively).

The involvement of upper gastrointestinal tract in patients included in the registry has been $49 \%$. Such involvement mainly affects the duodenum $(66.6 \%)$. This figure is similar to the results reported in other studies on gastrointestinal involvement in patients with FAP $(4,6,22-25)$.

A further characteristic of this disease are extraintestinal manifestations, being CHRPE the most common among our series of patients with an incidence of $65.7 \%$. Such incidence reaches $80 \%$ in other series (26). DT affects $9.1 \%$ of our patients; similar to the incidence reported in other series (27). It is important to diagnose and treat this type of tumor immediately as it is the second cause of death in patients who have undergone prophylactic colectomy $(7,28)$. Some factors have been associated with a higher risk of developing DT. None of these factors have allowed us to identify which patients in our registry have a higher risk of developing such tumor. Therefore in our opinion the best way to diagnose a DT early is to look for it through abdominal palpation and MR scan as the abdominal wall and the mesentery are the most common locations for this type of tumor (27).

Two of the registered families have a relative affected with AFAP. This difference in phenotype within the same family despite the same mutation could be due to mutations found that may affect processing of messenger RNA. This type of mutation involves a decrease in processing efficiency of messenger RNA (30) and this more or less efficiency would explain the different phenotypes in members of the same family.

Finally the occurrence of intestinal cancer during the course of the disease has only been in our cases associated with the abandonment of the monitoring and not with the type of mutation of these patients.

Some of our findings such as the inability to correlate the DT, the severity of involvement of upper segments and the development of rectal stump cancer with specific 
mutations described in the literature can be affected by low sample size due in part to the low participation of the invited hospitals. The creation of specialized units on the prevention of CRC and the understanding of the need to register all the affected families may help us in the coming years to obtain all and not just some of the goals.

\section{REFERENCES}

1. Morton DG, Macdonald F, Haydon J, Cullen R, Barker G, Hulten M, et al. Screening practice for familial adenomatous polyposis: the potential for regional registers. Br J Surg 1993; 80: 255-8.

2. Lynch HT, Smyrk T, McGinn T, Lanspa S, Cavalieri J, Lynch J, et al. Attenuated familial adenomatous polyposis (AFAP). A phenotypically and genotypically distinctive variant of FAP. Cancer 1995; 76: $2427-33$.

3. Elizabeth Half, Dani Bercovich and Paul Rozen. Familial adenomatous polyposis. Orphaned J Rare Dis 2009; 4: 22.

4. Wallace MH, Phillips RK. Upper gastrointestinal disease in patients with familial adenomatous polyposis. Br J Srg 1998; 85: 742-50

5. Brosens LA, Keller JJ, Offerhaus GJ, Goggins M, Giardiello FM. Prevention and management of duodenals polyps in Familial Adenomatous Polyposis. Gut 2005; 54: 1034-43.

6. Morpurgo E, Vitale C, Galandiuk S, Kimberling J, Ziegler C, Polk HC Jr. Clinical characteristics of Familial Adenomatous Polyposis and Management of duodenal adenomas. J. Gastointest Surg 2004; 8(5): 559-64

7. Griffioen G, Bus PJ, Vasen HF, Verspaget HW, Lamers CB. Extracolonic manifestations of familial adenomatous polyposis: desmoids tumors, and upper gastrointestinal adenomas and carcinomas. Scand J Gastroenterol Suppl 1998; 225: 85-91.

8. Olry De Labry Lima A, Sordo del Castillo L, García Mochon L, Epstein D, Bermudez Tamayo C, Villegas Portero R. An economic assessment of genetic testing for familial adenomatous polyposis. Rev Esp Enferm Dig 2008; 100(8): 470-5.

9. Giardello FM, Bresinger JD, Peterson GM, Luce MC, Hylind LM, Bacon JA, et al. The use and interpretation of comercial APC gene testing for familial adenomatous polyposis. N Engl J Med 1997; 336: 823-7.

10. Fernández-Suárez A, Cordero-Fernández C, García Lozano R, Pizarro A, Garzón M, Núñez Roldán A. Implicaciones clínicas y éticas del consejo genético en la poliposis adenomatosa familiar. Rev Esp Enferm Dig 2005; 97(9): 654-65.

11. Church J, Kiringoda R, LaGuardia L. Inherited colorectal cancer Registries in The United States: the State of the Union. Dis Colon Rectum 2004; 47: 674-8.

12. Obrador A, Thomson JPS. El Registro de Poliposis del Hospital de San Marcos de Londres. Gastroenterol Hepatol 2002; 25(4): 267-71.

13. Spiegelman AD, Thomson JP. Introduction, history and registries in familial adenomatous polyposis. London, Edward Arnold, 2004.

14. Bussey HJR. St Mark's Hospital Polyposis Register. Annual Report St Mark's Hospital 1970: 20-1.
15. Lockhart-Mummery P. Cancer and Heredity. Lancet 1925; 1: 427-9.

16. Reyes Moreno J, Ginard Vicens D, Vanrell M, Mariño Z, Garau I, Llompart A, Obrador Adrover A. Mejoría de la supervivencia de la poliposis adenomatosa familiar después del establecimiento de un registro. Med Clin (Barc). 2007; 129(2): 51-2.

17. Bülow S, Vulgo C, Faurschou Nielsen T, Karlsen \& Moesgaard L. Centralized Registration, Prophylactic examination and treatment results in improved prognosis in familial adenomatous polyposis. Scand J Gastroenterol 1995; 30: 989-93.

18. Friedl W, Caspari R, Sengteller M, Uhlhaas S, Lamberti C, Jungck $\mathrm{M}$, et al. Can APC mutation analysis contribute to therapeutic decisions in familial adenomatous polyposis? Experience from 680 FAP families. Gut 2001; 48: 515-21.

19. Caspari R, Olschwang S, Friedl W, Mandl M, Boisson C, Böker T, et al. Familial adenomatous polyposis: desmoids tumors and lack of ophthalmic lesions (CHRPE) associated with APC mutation beyond codon 1444. Hum Mol Genet 1995; 4: 337-40.

20. Enomoto M, Konishi M, Iwama T, Utsunomiya J, Sugihara K, Miya$\mathrm{ki} \mathrm{M}$. The relationship between frequencies of extracolonic manifestations and the position of APC germline mutation in patients with familial adenomatous polyposis. JPN J Clin Oncol 2000; 30(2): 82-8.

21. Crabtree MD, Tomlison IMP, Hodgson SV, Neale K, Phillips RKS Houlston RS. Explaining variation in familial adenomatous polyposis: relationship between genotype and phenotype and evidence for modifier genes. Gut 2002; 51: 420-3.

22. Kashiwagi H, Spigelman AD. Gastroduodenal lesions in familial adenomatous polyposis. Surg Today 2000; 30: 675-82.

23. Jalving M, Koornstra J, Götz J, Van der Waaij LA, de Jong S, Zwart $\mathrm{N}$, et al. High-grade dysplasia in sporadic fundic gland polyps: a case report and review of the literature. Eur Journal of Gastroent and Hepatol 2003; 15: 1229-33.

24. Hofgärtner W, Thorp M, Ramus M, Delorefice G, Chey WY, Ryan CK, et al. Gastric adenocarcinoma associated with fundic gland polyps in patient with attenuated familial adenomatous polyposis. Am Journal of Gastroenterology 1999; 94: 2275-81.

25. Cordero-Fernández C, Garzón-Benavides M, Pizarro-Moreno A García-Lozano R, Márquez-Galán JL, López-Ruiz T, et al. Gastroduodenal involvement in patients with familial adenomatous polyposis. Prospective study of the nature and evolution of polyps: evaluation of the treatment and surveillance methods applied. Eur J Gastroenterol Hepatol 2009; 21 (10): 1161-7.

26. Vasen HFA, Möslein G, Alonso A, Aretz S, Berstein I, Bertario L, et al. Guidelines for the clinical management of familial adenomatous polyposis (FAP). Gut 2008; 57: 704-13.

27. Pikaar A, Notier JW, Griffioen G, Vasen HF. Desmoids tumors in patients with familial adenomatous polyposis. Ned Tijdschr Geneeskd 2002; 146: 1355-9.

28. Arvanitis ML, Jagelman DG, Fazio VW, Lavery IC, McGannon E. Mortality in patients with familial adenomatous polyposis. Dis Colon Rectum 1990; 33: 639-42.

29. Nieuwenhuis MH, Vasen HFA. Correlations between mutation site in APC and phenotype of familial adenomatous polyposis (FAP): a review of the literature. Crit Rev Oncol Hematol 2007; 61: 153-61.

30. Aretz S, Uhlhaas S, Sun Y, Pagenstecher C, Mangold E, Caspari R, Möslein G, et al. Familial adenomatous polyposis: aberrant splicing due to missense or silent mutations in the APC gen. Hum Mutat 2004; 24(5): 370-80 